\title{
Anmeldelse:
}

\section{At gøre en forvirrende verden forståelig}

Af Erik Beukel

International PolitikNU er anden udgave af en grundbog til samfundsfag på A-niveau på de gymnasiale uddannelser. Formålet er at give en letforstålig indføring $i$ international politik ved at fremlægge begreber og problemstillinger, som gør verden begribelig. Bogen har fordele, men der er også mangler.

Morten Winther Bülow og Tonny Brems Knudsen (red.): International PolitikNU - magtbalance, værdier og samarbejde. Systime, 2015.

Verdens befolkning på godt syv milliarder mennesker lever i geografisk afgrænsede og suveræne stater. FN er den mest omfattende mellemstatslige organisation med 193 medlemslande. De knap 200 suveræne og uafhængige stater er på mange måder bundet sammen, og skellet mellem 'egne' og 'andres' anliggender er ikke ligetil. Staterne er de vigtigste aktører i international politik, men også andre aktører har betydning. Det afgørende er, at der ikke findes nogen verdensregering til at regulere staternes adfærd, og i den forstand kan man sige, at det internationale system bestående af suveræne stater er anarkisk.

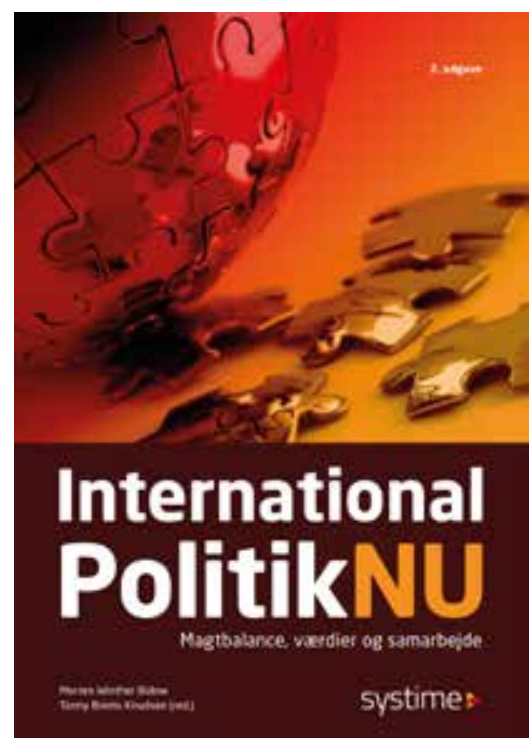

Men der er ikke anarki i betydningen kaos. Der findes strukturer, som påvirker og giver mønstre i staternes adfærd, og international politik er præget af både samarbejde og konflikter. Sideløbende med skiftende magtbalancer og værdi- og interessekonflikter er samarbejdsvaner og fælles interesser en indbygget del af det internationale samfund. Suveræne staters beslutninger formes altid i en eller anden grad af andre stater, af ikke-statslige aktø-

Erik Beukel er dr. scient. pol. og tidligere seniorforsker på Dansk Institut for Internationale Studier (DIIS). 
rer og af strukturer i den omgivende verden.

Alle stater er lige i den forstand, at alle er suveræne, men magt og indflydelse er højst ulige fordelt mellem de suveræne og uafhængige stater. Dette overses, når stolte regeringsledere og politikere gentager 'vi er et suverænt land og bestemmer selv'. Ideen om staters suverænitet er ikke uden mening i international politik i dag, men som andre plusord går der nemt inflation $i$ brugen af det. Suveræne stater 'bestemmer selv', men har sjældent fuld kontrol med konsekvenserne af deres beslutninger.

\section{Bogens opbygning}

Bogen er skrevet af forskere fra Institut for Statskundskab, Aarhus Universitet samt enkelte andre. Den er struktureret i fem dele og 14 kapitler. De to redaktører redegør på udmærket måde for ovennævnte grundlæggende træk ved international politik i første kapitel 'Teorier, begreber og spørgsmål,' som sammen med de to følgende kapitler udgør Del 1 -Den Internationale Orden. Kapitel 2 'Det internationale samfund og spørgsmålet om verdensorden' er skrevet af Georg Sørensen; og kapitel 3 'International politisk økonomi - globalisering, udvikling og kriser' af Jørgen Dige Pedersen.

Del 2 - Gamle og Nye Stormagter gennemgår i fire kapitler udvalgte lande og landegrupper. Kapitel 4 'USA - en global supermagt i en regionaliseret verden' er skrevet af Derek Beach; kapitel 5 'De nye BRIKS-stormagter: Fra økonomi til politik' af Mette Skak; kapitel 6 'Kina som stormagt' af Clemens Stubbe Østergaard; og kapitel 7 'Den Europæiske Union i international politik' er udformet af Knud Erik Jørgensen.

Del 3 - Sikkerhed og Konflikter - består af tre bidrag. Først har Mette Skak i kapitel 8 en indledning om 'Sikkerhed, krig og konfliktløsning'; Jens Nauntofte skriver i kapitel 9 om 'Det konfliktfyldte Mellemøsten'; mens Morten Valbjørn i kapitel 10 fortæller om 'Det sekteriske Mellemøsten'.

Del 4 - Værdier, Normer og Institutioner - har tre bidrag: kapitel 11 af Jørgen Grøndahl Glavind om 'Normer i International Politik'; kapitel 12 'Demokratisering, menneskerettigheder og problemet med svage stater' af Georg Sørensen; kapitel 13 'Civilisationer og religion i international politik' er skrevet af Tina Magaard.

Til sidst i Del 5 - Danmark i Verden - har Rasmus Brun Pedersen et bidrag 'Danmark i verden - udenrigs- og sikkerhedspolitik samt bistandspolitik'.

Tilsammen illustrerer de 14 kapitler, at ingen enkelt tilgang er tilstrækkelig for at forstå den forvirrende verden. Kapitlerne 9, 10 og 11 er tilføjet efter udgivelsen af første udgave, og alle tre hører til bogens mest udbytterige. Især bør kap. 11 om normer i international politik fremhæves for analysen af, hvordan de normer, der blev henvist til i forbindelse med interventionerne og ikke-interventionerne i Irak, Libyen og Syrien, viser centrale normkonflikter i international politik: Var det afgørende en norm om beskyttelse af menneskerettigheder, en norm om ikke-intervention i suveræne staters indre anliggender, om præventivt selvforsvar eller ikke-brug af militær magt?

Kap. 3 giver en god oversigt over forskellige tilgange til globalisering, udvikling og kriser. Kap. 7 opererer med en værdifuld skelnen mellem EU som en væsentlig international aktør og EU som are$n a$ for medlemslandenes diplomati.

Også andre kapitler indeholder nyttige iagttagelser. Bl.a. kap. 2, der erindrer om, at Sovjetunionens spektakulære sammenbrud 
og dannelsen af en række nye stater fandt sted uden krig. Det havde de færreste troet kunne ske blot få år før, at det faktisk skete. Tilsvarende får vi i kap. 13 om civilisationer og religioner et indblik i fænomener, hvis betydning kun få forudså.

Bogen har mange gode figurer og illustrationer, der øger dens anvendelighed i undervisningen. En oversigt over yderligere litteratur og websider efter hver artikel havde dog været nyttig. Resten af denne anmeldelse vil nærmere diskutere enkelte af bogens bidrag, især sådanne, hvor jeg savner noget og har forslag til forbedringer.

\section{USA}

Kapitel 4 om USA analyserer den globale supermagts rolle i verden ud fra tre forskellige teorier: strukturel realisme med vægt på magtfordelingen mellem stater; neoklassisk realisme, der lægger vægt på hver stats særtræk; og det liberale perspektiv (forstået som teoretisk retning) med dets vægt på en verden præget af samarbejde i institutioner, samhandel og demokrati.

Anvendelsen af den generelle IP-fagterminologi (strukturel realisme, neoklassisk realisme, osv.) kan virke påklistret i en artikel, der skal være en letforståelig indføring i USA's rolle i verden.

Spørgsmålet er, om det ikke havde været mere frugtbart at dreje tilgangen ved at tage udgangspunkt i USA's særtræk og den meget sammensatte amerikanske selvforståelse på eliteniveau og det brede folkelige niveau. Forfatteren omtaler skiftene mellem en 'missionsdoktrin' og en 'eksempeldoktrin' (USA som the city on the hill), der lægger vægt på amerikansk 'exceptionalisme', og som er blevet udmøntet $\mathrm{i}$ både isolationisme og interventionisme.
Hertil kunne føjes know nothing-bevægelser, der har dybe rødder i amerikansk historie, og som på det seneste er blomstret op igen. Det er også vigtigt at erindre, at USA har en lang tradition for dybtgående analyser bag landets udenrigspolitik. Ved at bruge neoklassisk realisme som overordnet analyseramme i stedet for som én af tre forskellige tilgange bliver det også relevant at inddrage idétraditioner, der udspringer af de to andre tilgange. Pindehuggeri? Måske, men en smule sofisteri kan til tider fremme forståelsen.

\section{Kina og Rusland}

Artiklen om Kina ser landet som overvejende en 'status quo'-magt - måske en ambitiøs sådan - snarere end en revisionistisk magt, og risikoen for overreaktioner fra et presset USA fremhæves. Konfliktpotentialet i forholdet til andre lande i Østasien nedspilles, og bidraget er ikke præget af den store forståelse for, at Kinas nabolande føler sig truede af Kinas ambitioner i det Sydkinesiske Hav, og at de ønsker at fastholde et amerikansk engagement i området.

Kinas enorme økonomiske vækst gør, at landet er indehaver af verdens største valutareserver, som for en stor del er anbragt i amerikanske statsgældsbeviser. Alt $i$ alt er verdens to største økonomier flettet tæt sammen, så hvis det ene lands økonomi går ned, følger den andet - og vi andre - med i afgrunden. I en ny udgave af bogen vil det være en god ide at ofre et selvstændigt kapitel på det yderst sammensatte amerikansk-kinesiske forhold.

Rusland omtales alene som en af de fem BRIKS-stormagter (sammen med Brasilien, Indien, Kina og Sydafrika), der alle for få år siden var vækstøkonomier, som indvarslede et magtskifte i den globale økonomi. 
Artiklen er præget af forbehold over for BRIKS-samarbejdets vægt $\mathrm{i}$ international politik. Ruslands rolle burde være gennemgået og diskuteret i et selvstændigt kapitel. Hvad er det særlige ved Putin-Ruslands udenrigspolitik, og hvad betyder annekteringen af Krim og interventionen i Ukraine for forholdet til Vesten?

Danmarks engagement i de baltiske lande gør det også relevant at diskutere konsekvenserne for dansk sikkerhedspolitik i Østersøområdet. Det fører over i bogens sidste kapitel om dansk udenrigspolitik.

\section{Fodnoter}

I omtalen af fodnotepolitikken i 1980'erne skriver forfatteren, at "oppositionen tvang regeringen til at tage en lang række forbehold i samarbejdet i EF- og NATO-regi" (s. 306). Ordet 'tvang' leder forståelsen af den sikkerhedspolitiske strid under Schlüter-regeringen i en gal retning. I et parlamentarisk system som det danske kan en regering af et flertal i Folketinget ikke tvinges til at følge en bestemt politik, som den er grundlæggende uenig i.

Vedtagelsen af 22 dagsordener, hvor næsten alle imod regeringens ønsker pålagde den at indsætte fodnoter i NATOkommunikeer, kunne være gjort til kabinetsspørgsmål, dvs. at regeringen på forhånd meddeler, at sagen betragtes som så vigtig, at den vil træde tilbage eller udskrive valg, hvis den kommer i mindretal. Det valgte Schlüter-regeringen ikke at gøre før i foråret 1988 ved det såkaldte anløbsvalg.

Problemet kan uddybes ved at se på sammenhængen med Danmarks sikkerhedspolitiske situation under den kolde krig.

Fodnotepolitikken er blevet kritiseret som letbenet og uden et minimum af analyse af det totalitære Sovjetunionens militærpolitik og konsekvenserne for Danmark i lyset af vor placering nær Jerntæppet. Kritikken bygger på antagelser, hvis holdbarhed i sidste ende hverken kan bevises eller modbevises, og den indeholder en i princippet usikker afvejning af risici ved forskellige handlemuligheder. Denne usikkerhed er imidlertid central ved alle vigtige sikkerhedspolitiske beslutninger.

Men uanset disse 'på-den-ene-side-ogpå-den-anden-side'-betragtninger må en vurdering af fodnotepolitikken tage udgangspunkt i ovennævnte kritik - hvis substans denne anmelder er enig i - og ikke i et skævt argument om, at regeringen af fodnoteflertallet blev tvunget til noget, den var imod.

Denne parlamentariske-cum-udenrigspolitiske knude kunne fortjene nærmere behandling og gøre særtræk ved dansk udenrigspolitik og sammenhængen med mindretalsparlamentarisme mere forståelig.

\section{International aktivisme}

Den sidste del af kapitlet gennemgår, hvordan dansk krigsdeltagelse i 00'erne som det mest markante udtryk for en ny international aktivisme fik et særligt værdipolitisk skær, der med udgangspunkt i offensive liberale og nykonservative ideer argumenterer for, at demokratiske lande ikke alene har ret, men også pligt til at udbrede demokratiske værdier. Når det gælder støtten til den amerikansk-ledede krig mod Irak i 2003, kunne det være omtalt og diskuteret, at den ifølge. regeringen Fogh Rasmussen også havde andre formål så som respekt for $\mathrm{FN}$, afvæbning af en brutal diktator med masseødelæggelsesvåben og solidaritet med USA.

Mens der tidligere fandtes en del succes- 
fulde transformationer fra diktatur til demokrati (Latinamerika, Østeuropa, Baltikum), har senere eksempler på fjernelse af en diktator efter intervention udefra resulteret i kaos uden liberalt demokrati (Irak og Libyen).

I USA har der ved siden af ideen om offensiv demokratispredning længe eksisteret en udenrigspolitisk tænkning, som fremhæver, at dybtliggende traditioner for autoritære styreformer skaber nogle uoverkommelige grænser for at udbrede frihed og demokrati til stadig flere lande på Kloden.

I dansk udenrigspolitik bremser den nære alliance med USA for en sådan erkendelse, hvis den indebærer kritik af Washington.
I de kommende år vil flygtninge- og migrationsstrømme og terrorisme sætte nye rammer for dansk udenrigspolitik. Og med to afgørende præsidentvalg på begge sider af Atlanterhavet skimtes i horisonten bl.a. EU's kollaps, sammenbrud i det globale regelbaserede handelsregime (WTO) og aggressiv russisk hybridkrig mod et baltisk land, som NATO står famlende overfor.

Men mørke skyer behøver som bekendt ikke ende med voldsomt uvejr. Derimod kan de være en god anledning til at genoverveje, hvor langt international aktivisme for at tjene 'ædle’ mål bør fortrænge vitale udenrigsøkonomiske og sikkerhedspolitiske interesser. 